\title{
Registrar's Statutory Duties under the Malaysian Land Registration System: A Little Too Much to Handle!
}

Noraziah Abu Bakar, Habibah Omar, Norliza Abd Hamid, Mazlifah Mansoor, Sarah Munirah Abdullah, Siti Sarah Sulaiman, Nurazlina Abd Raof, Hariati, Mansor

To Link this Article: http://dx.doi.org/10.6007/IJARBSS/v11-i10/10719

DOI:10.6007/IJARBSS/v11-i10/10719

Received: 06 August 2021, Revised: 05 September 2021, Accepted: 25 September 2021

Published Online: 12 October 2021

In-Text Citation: (Bakar et al., 2021)

To Cite this Article: Bakar, N. A., Omar, H., Hamid, N. A., Mansoor, M., Abdullah, S. M., Sulaiman, S. S., Raof, N. A., \& Hariati, M. (2021). Registrar's Statutory Duties under the Malaysian Land Registration System: A Little Too Much to Handle! International Journal of Academic Research in Business and Social Sciences, 11(10), $659-669$.

Copyright: (c) 2021 The Author(s)

Published by Human Resource Management Academic Research Society (www.hrmars.com)

This article is published under the Creative Commons Attribution (CC BY 4.0) license. Anyone may reproduce, distribute, translate and create derivative works of this article (for both commercial and non-commercial purposes), subject to full attribution to the original publication and authors. The full terms of this license may be seen at: http://creativecommons.org/licences/by/4.0/legalcode

Vol. 11, No. 10, 2021, Pg. $659-669$

Full Terms \& Conditions of access and use can be found at http://hrmars.com/index.php/pages/detail/publication-ethics 


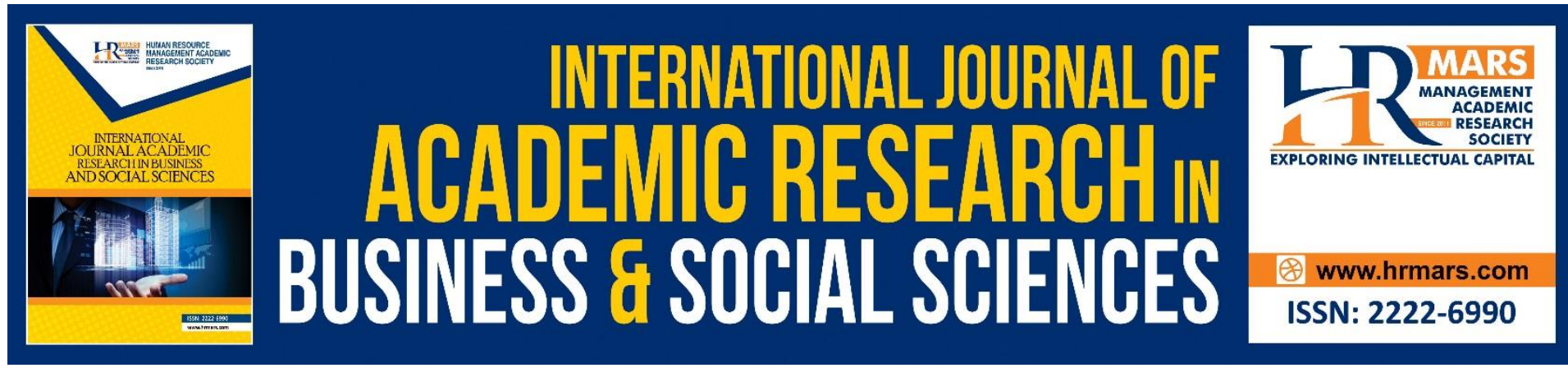

\title{
Registrar's Statutory Duties under the Malaysian Land Registration System: A Little Too Much to Handle!
}

\author{
Noraziah Abu Bakar ${ }^{1}$, Habibah Omar², Norliza Abd Hamid², \\ Mazlifah Mansoor ${ }^{4}$, Sarah Munirah Abdullah ${ }^{5}$, Siti Sarah \\ Sulaiman ${ }^{6}$, Nurazlina Abd Raof ${ }^{7}$, Hariati, Mansor ${ }^{8}$ \\ 1,2,3,4,5,6,7Faculty of Law, Universiti Teknologi MARA, 40450 Shah Alam, Selangor, Malaysia, \\ ${ }^{8}$ Universiti Teknologi MARA Johor, 81750 Masai, Johor Malaysia
}

\begin{abstract}
The Registrar will ensure that the instrument fits for registration under the National Land Code 1965 (NLC). This duty is in sync with the statutory duty of the Registrar to provide an accurate Land Database. The Registrar also has a responsibility to facilitate registration. Nonetheless, vast discretionary power accorded to the Registrar makes them an authority to be dependent upon by others, for example, enforcement agencies in the event of crimes involving land. This paper aims to examine the extent of the Registrar's discretion in dealing with applications, not within the purview of the NLC, made by the other government agency. Clear guidelines on this issue may facilitate effective cooperation between agencies and simultaneously does not prejudice a bona fide purchaser for value who might become the victim of non-endorsement of the notice of seizure by the Registrar from other legislation. This paper utilises the doctrinal legal research and secondary data, with the NLC and AML/CFT legislation as the primary source. Secondary sources include decided cases, articles in academic journals, books, and online databases.
\end{abstract}

Keywords: Dealing, Illegal Documents, Registrar, Land Database, Bona Fide Purchaser

\section{Introduction}

The Registrar ensures that the instrument is fit for registration under the National Land Code 1965 (NLC) (Teo, 2012; Sihombing, 2019). In determining the fitness of the registration, the Registrar has a responsibility to facilitate registration. However, the power of inquiry provided under Section 302 of the NLC does not include the power to inquire into the validity of the instruments presented for registration. Besides that, the power of rectification as provided under Section 380 of the NLC is another weapon accorded to the Registrar. It remains unclear as to the errors or mistakes that could be rectified by the Registrar. In Island \& Peninsular Development Berhad \& Anor v Legal Advisor, Kedah [1973] 2 MLJ 71, the court decided that only clerical errors committed by the Land Registry can be rectified under Section 380 of the NLC. In addition to these powers, Section 320 of the NLC empowers the Registrar to enter a Registrar Caveat, where the words "necessary or desirable" is used to indicate the 
vast power given to the Registrar in carrying out his duty. In addition to that, Section $321(3)$ of the NLC allows the Registrar to withdraw the Registrar Caveat on his own motion.

Nonetheless, the vast discretionary power accorded to the Registrar makes them an authority to be dependent upon by others. However, concerning any freezing order by another legislation that is not provided under the NLC, the extent to which the Registrar is empowered to comply with any application remains unclear. On this note, there have been issues relating to the extent of the power of the Registrar in honouring requests of other agencies such as the Malaysian Anti-Corruption Commission (MACC) in freezing order on land that has become the subject of criminal investigation. Will, the duty of the Registrar in effecting registration under the NLC, prevails over the freezing order from other legislations?

The NLC is the primary statutory source relating to land law in West Malaysia. It was enacted as a standard and uniform law relating to land matters by adopting the Torrens System. Since land is under the privilege of the state authority under the Federal Constitution, section 14 of the NLC provides that each state is empowered to make its own state land rules to carry out the object and the purpose of the NLC. The NLC under section 8 also provides for consultations and meetings between the Director-General of Land and Mines (Federal Government) and the State Directors concerning any administrative issues and land matters. In addition to the above, The Department of Director General of Lands and Mines also prepared and issued a Manual on the National Land Code. This effort is made to assist the land administration officers, particularly the Registrar of Land Titles (the Registrar) at the state level, to accomplish their responsibilities as provided under the NLC. The law accords the authority in the form of discretionary power.

\section{Objectives}

The objective of this paper

- to review the discretionary power of the Registrar under the NLC and determine whether it ran in contradiction with the Registrar's responsibility to give effect to the freezing order applications derived from other legislation that is not being prescribed for under the NLC.

- to examine the extent of the duty imposed on the Registrar to honour the freezing order application in a situation where an instrument of dealing is presented for registration.

\section{Methodology}

This paper employs doctrinal research to analyse the discretionary power granted to the Registrar under the NLC relating to the registration of the instrument of dealings. The discussion in this paper is limited to looking at the laws and theoretical aspects of the Registrar's discretion in land administration. No empirical analysis was made as it focuses on a doctrinal analysis and theoretical discourse. It also seeks to review the legal implication of freezing orders applied under other legislation and analyse the extent of a duty imposed on the Registrar in complying with the external application outside the purview of the NLC. Thus, the findings have gathered and analyzed secondary data and sources from decided cases, academic journals, official documents from the Bar Council, and online databases. The data is examined via a content analysis approach and doctrinal study. 


\section{Literature Review \\ The Role of a Registrar in Land Administration}

A registrar is essential personnel in land administration. He is one of the figures responsible for managing land in Malaysia and contributes towards strong land governance. Solid and effective land governance ensures land rights are protected, and national laws are adequately enforced (Azadi, 2020). Strong land governance makes decision-making becomes more transparent and inclusive (Lavigne Delville, 2007) and, at the same time promotes good governance (Enemerak et al., 2009; Gisselquist, 2012). Indeed, one of the factors that contribute to successful land governance is land tenure security (Magel and Wehrmann, 2001; Deininger et al., 2011; Teklemariam et al., 2015). Hence, the Registrar, being part of the land administration governing body, is expected to comply and perform his duty under the law i.e., the NLC relating to land tenure security.

The Registrar in Malaysia is appointed according to section 12 of the NLC to perform critical administrative functions. Among the functions performed by the Registrar are; determining the fitness of the documents of registration vide Section 297 of the NLC, replacement of lost titles under Section 175 and 175A of the NLC, making corrections on the registrar documents of titles vide Section 380 of the NLC, enter a Registrar Caveat under Section 320 of the NLC and withdraw the Registrar Caveat on his own motion under Section 321 of the NLC. The Registrar's duty on imposing freezing order is not provided for under the NLC. However, under other legislation, such as section 51 of the Anti-Money Laundering, AntiTerrorism Financing and Proceeds of Unlawful Activities Act 2001 (Act 613), imposed on the Registrar to honour notice of seizure on any immovable property that is a subject matter of an offence. In order to effectively perform these roles, the Registrar is allowed to exercise his discretion. The law confers such discretion, ie, the NLC.

\section{The Registrar's Exercise of Discretion}

Discretion, according to Judge Marvin Frankel - is law without order. It is regarded as a residual concept where subjective judgment is allowed to be exercised by statutes, rules, or judicial decisions (Applegate 1982). Indeed, discretion is necessary for effective administration. However, the unchecked exercise of discretion can lead to abuse of power (Omar, Mansoor, Ramli and Mohammad Salleh, 2020). Hence, in the context of land administration, it is impossible for the Registrar of land to perform his functions under the NLC effectively without a degree of discretion. In this context, the scope and extent of discretionary powers of a land registrar will be explored.

\section{Registrar's Discretion - Determining the Fitness of Registration}

Before introducing the NLC, the land administration system was mainly set up to collect revenue through a tax imposed on proprietors by the government (Maidin et al., 2008). This function later evolved into a system where the State Authority functions as the registering authority that maintains the record of transactions to confer indefeasible titles or interest (as the case may be) upon registration of the necessary instruments. In accepting the instrument of dealings for registration section 297 of the NLC, the Registrar is obliged to determine the fitness for registration of every instrument received and entered into the Presentation Book. Since the process in determining the fitness of the instrument of dealing is detailed in the provisions, it serves as a mandatory guideline in determining the fitness of registration of the instrument of dealings. Such exercise of discretion to effect registration is guided by the law, within the scope of the NLC. 
Section 297 and 301 of the NLC empower the Registrar to decide an instrument of dealing as regular and thus fit for registration if, on the surface, there is no indication of any irregularity. The document will be deemed to have complied with the requirement of the NLC. As such, the Registrar is required by law to accept the instrument for registration. However, suppose the instrument is not accompanied or supported by other required documents. In that case, section 302 of the NLC allows the Registrar to make inquiries regarding the missing document and take necessary measures to ensure the production of such documents. Nonproduction of such documents warrants the exercise of the Registrar's discretion to effect registration (upon satisfactory explanation) or rejects it. In the case of Maria Rochele Silva Sarabia $v$ Registrar of Lands and Surveys \& Anor [2016] 7 MLJ 52, the conduct of the Registrar by registering the transfer instrument despite the existence of the plaintiff's caveat is wrongful. This scenario seems to suggest that the NLC closely guides the exercise of the Registrar's discretion in the registration of instruments of titles.

Indeed, the Registrar shall uphold his role diligently. As a registering authority is responsible for the keeping and monitoring the original database of land and it must reflect an accurate and genuine database that is reliable to circumvent any element of uncertainty to which the land is subject that would undermine the primary purpose of the Torrens System (Teo, 2012). In the case of Mohamad bin Buyong $v$ Pemungut Hasil Tanah Gombak \& Ors [1982] 2 MLJ 53, an entry was made in the Register on the day that the Form 14A together with a purported power of attorney but without the production of the original title deed was presented by the applicant. It was a bare entry without the seal of the Registrar. Subsequently, the land office received a letter from the second respondent claiming that she never signed a power of attorney. The Collector considered the matter and decided to reject the instrument in accordance with Section 298 of the NLC. Later on, the transfer between the second respondent with third and fourth respondents was registered. The appellant appealed against the decision of the Registrar. There was no registration effected for the first registration since it was only recorded and not sealed under the hand of the Registrar. Therefore, it could be deleted or cancelled. The case is in line with the concept of "registration" as making of a prescribed memorial in the Register Document of Title (RDT) under the hand and seal of the registering authority" (Wong, 1976).

The Registrar's exercise of power in determining the fitness of the instrument of dealings is administrative in nature. Even though the power is discretionary in nature, Section 303 of the NLC states the limitation of the Registrar's exercise of discretion in determining the fitness of the documents; that is, he shall not inquire into the validity of the instruments. Hence, in this context, the Registrar's discretion is relatively narrow and is limited to determining the fitness of instruments. This is because the NLC specifies mandatory provisions where noncompliance will attract severe repercussions to the Registrar himself as an officer of the NLC responsible for this issue. The Registrar can be personally liable for any carelessness or negligence in exercising his power as decided in the case of Pow Hing \& Anor $v$ Registrar of Titles, Malacca [1981] 1 MLJ 155

In this context, the NLC is very rigid and provides a minimal guideline on discretion. To some extent, the law victimises the Registrar in the performance of his duty. Instead, the law should allow for a more relaxed approach with a quasi-judicial function that clarifies the extent of the Registrar's discretionary power. If the scope of duty is made crystal clear, it will provide more excellent protection against civil suits to the Registrar when performing his official duty under the Code. Indeed, when carrying out his duty in the name of the office, the Registrar must exercise due care in making decisions, act in good faith, make decisions 
and exercise his duty following the law, and hence be protected by Section 22 of the NLC.

In the case of Bagan Serai Housing Estate Sdn Bhd $v$ Pentadbir Tanah Daerah Seberang Perai Tengah \& Anor [2002] 5 MLJ 1, the court decided that only an officer appointed by the State Authority can invoke protection accorded under the section. Similarly, in the decided case of Uptown Property Sdn Bhd v Pentadbir Tanah Wilayah Persekutuan [2012] MLJU 131, the Learned Justice Prasad Sandosham Abraham denied the Land Administrator of the protection accorded under Section 22 of the NLC. The judge stated that since the officer was negligent, the conduct of the officers involved showed a failure to carry out their functions correctly, which can hardly be construed to have carried out their duties in good faith. In this case, the proprietor's name was mistakenly endorsed in the Land Database as a different name. Instead of "Uptown," it was endorsed as "Liptown" during the conversion process from the manual title deed to a computerised printout title deed. In the case of Shayo (M) Sdn Bhd $v$ Nurlieda Sidek \& Ors [2013] 1 CLJ 153, the defendant's name was endorsed in the computerised printout title deed. However, luckily the manual title deed is still in possession of the original owner.

\section{Registrar's Discretion - Replacement of Lost Titles}

The Registrar, as the registering authority, is also empowered under Section 175 of the NLC to replace any lost or destroyed title deed. The Registrar is also empowered to replace the RDT if it is destroyed under Section 175A of the NLC. It is provided that the Registrar shall conduct an inquiry, and the process is clarified in Chapter 13 of the Manual on the National Land Code. Suppose the provisions and the steps described by the Manual on the National Land Code have complied. In that case, the fraudulent activities may be curbed since the process for replacement is stringent, and it would not be easy to replace a title deed. A faceto-face inquiry would indirectly deter a potential fraudster from any attempt to impersonate the actual proprietor.

\section{Registrar's Discretion - Power to Correct Errors on the Registrar Document of Title (RDT)}

Another distinctive discretionary power of the Registrar is the power of rectification under the NLC. The power to correct an error in the RDT is provided under Section 380 of the NLC. This section provides that if the RDT has been registered with the wrong name, misdescription of land or boundaries, or other error or omission, or any memorial or entry has been made in error in the document of title or other instrument relating to land or other error or omission, the Registrar may make such correction on the RDT as appropriate. The court has clarified the extent of the power conferred under this section in Island \& Peninsular Development Berhad \& Anor v Legal Advisor, Kedah [1973] 2 MLJ 71. In this case, the court decided that the power to correct errors under the section is only confined to an error or mistakes made by the Registry of Land Titles and not extended to the error committed by the parties. It should also restrict errors due to a clerical or administrative mistake by the Registry (Wong, 1976).

The English land registration system allows the register to be corrected if it turns out that an entry was wrongly registered or deregistered while ensuring indemnity will be available for those whose property rights are prejudiced by the corrections (Simon, 2018). The test to ascertain whether it is considered that the Registrar should exercise his discretionary power of correction by reviewing where amongst other things, the Registrar makes an entry in the Register that he would not have made; or makes an entry in the Register that he would not have made in the form in which it was made, or deletes an entry which he would not have 
deleted; had he known the true state of affairs at the time of the entry or deletion (Harprum et al., 2012). This is crucial for registered land because they determine when the security of registered title may have to give way to more important values, such as the need to give relief against the effect of error (Simon, 2019).

In New Zealand, the power to correct errors on RDT is also seen as opening a "Pandora Box" and shall affect the certainty offered by the Torren System (Hinde et al., 2004). In Minister of Conservation v Maori Land Court [2008] NZCA 564, the court decided that the Registrar's power to correct errors under the statute should not be invoked to impeach an indefeasible title. The power should be used in a restrictive manner. However, the Registrar's power is necessary to provide both dynamic and static security of registration of the conveyancing system as it merely exists alongside the various exceptions to indefeasibility (Roberts, 2015; Cooper, 2017). The discretionary power accorded to the Registrar to rectify the Register is guarded adequately by most jurisdictions. In West Malaysia, the restrictive manner in using this power is still subsisting as limited to the power to rectify any clerical and administrative errors on the RDT.

The above discussion reflects the discretionary powers of the Registrar exercised pursuant to the authority under the NLC. Indeed, the exercise of discretion is heavily guided by the empowering law, i.e., the NLC that creates the office and role of the Registrar himself. The issue is, to what extent will such authority and discretion under the NLC be preserve when the Registrar is faced with a direction given by another authority acting under other legislation.

\section{Registrar's Exercise of Discretion - Freezing Orders from Other Written Law}

Undeniably, the authority of the Registrar is sourced from the NLC. The NLC does not provide any reference to any other law regarding the performance of the Registrar's functions and duties. When such incidents happen, there is bound to be a challenge on the exercise of the Registrar's discretion. Indeed, the discretionary power exercised by the Registrar to delete the memorial became an issue in the case of Lau Yong Hing $v$ The Bank of Punjab \&Ors and other Appeals [2018] 4 MLJ 88. In this case, the Registrar withdraws the Registrar Caveat on lodged upon the Royal Malaysian Police (RMP) application. The RMP identified, froze, and seized a property purchased by a criminal who had allegedly defrauded the plaintiff's Bank of Punjab. The property was registered under the name of the suspect. It was later that RMP requested the Registrar to lodge a Registrar Caveat. Subsequently, the Public Prosecutor issued a notice of seizure of the property under section 51(1)(1) of the Anti-Money Laundering, Anti-Terrorism Financing and Proceeds of Unlawful Activities Act 2001 (Act 613) and served the same to the Registrar. However, he failed to endorse the terms of the notice of seizure on the RDT, even though he was required to do so under section 51(2) of Act 613. Simultaneously, the Bank of Punjab applied for a vesting order which the High Court duly granted.

Meanwhile, the former owner, Lee, and Ewe sued the Pakistani for the non-payment of the balance purchase price and obtained a judgment in default without notifying the Bank of Punjab. Lau Yong Hing became the successful bidder in an auction and paid the total auction price. He applied for the removal of the Registrar Caveat to register the certificate of sale. Under section 321 of NLC, a Registrar's caveat "shall continue in force until the Registrar cancels it." The provision states that a registrar can cancel the caveat on his motion or upon the land proprietor's application or a court's order under section 418 of NLC. However, section 321 of the NLC does not provide the guiding principle for the Registrar to exercise his 
discretionary power, especially when acting without any application from the land proprietor. In this case, using section 400 of the NLC, the Registrar cancelled the registrar caveat. The Registrar removed the Registrar before RMP responded to his notice. In affirming the decision of the High Court, the Court of Appeal expressed that the registration of the certificate of sale was void. The court ordered it to be cancelled because any registration of the instrument of dealings is void after the notice of seizure and sale is entered onto the land even though the Registrar has not endorsed it.

With due respect to the decision of the court, the issue that ought to be considered in this case is whether the Pakistani who has obtained the title through registration of the property without paying the total amount of the balance purchase price is indefeasible? The court, in this case, had disregarded the legality of the ownership of the Pakistani registered as the proprietor of the land in question before allowing the application for notice of seizure to stop any registration of land transactions. In the recent case of Low See Hee \& Sons Realty Sdn Bhd $v$ Low Earn Leng \& Ors [2021] MLJU 282, it was ordered by the court that the registration of Form 14A be cancelled because the purchaser has breached the sale agreement by failure to pay the total balance purchase price. The Torrens System provides certainty and reliance on the RDT as provided under section 89 of the NLC that reflects a mirror of the sort that provides the descriptions of the land. Anyone can safely rely on it without to need to investigate beyond the Register that serves as a curtain (Dass, 1963; Sihombing, 2019). It is unfair to impose the duty to investigate beyond the RDT, especially in a case where endorsement has not been made by the Registrar, such as in the case of Lau Yong Hing.

The primary duty of the Registrar is to ensure that registration of the instruments of dealings and other related documents to land could be registered effectively (Noraziah, 2019). Hence, any duty imposed on the Registrar has been stipulated in the NLC. When the NLC is silent as to the requirements of other written laws, it becomes a grey area as to the extent of the discretionary power that the Registrar could exercise. Can the Registrar refuse to acknowledge the application by not conceding to the freezing order's application of land provided under another written law, and has the Registrar acted mala fide and exceeding the power granted to him under the NLC? The NLC is silent on the extent of a duty imposed on the Registrar to endorse any freezing orders on the land by any other written law such as Act 613. Non-endorsement of the prohibition by the Registrar could adversely affect any parties who intend to enter into a land transaction on the said land.

The legal principle underpinning a Registrar's duty to enter Registrar's caveat is when he believes it is necessary or desirable to protect the Federation or the State Authority's interest. It means that he ought to enter the Registrar's caveat when he is informed of the need to protect the Federation or the State Authority's interest as stated under section 320 of the NLC. In this context, section 320 of NLC provides for the lodgement of a Registrar Caveat and not any other freezing order. Whereas section 51 of the Anti-Money Laundering, Anti-Terrorism Financing and Proceeds of Unlawful Activities Act 2001 (Act 613), the Public Prosecutor may serve a notice of seizure to the Registrar responsible for land titles when any immovable property is a subject matter of an offence under Act 613.

There is, however, a conflict between section 320 of the NLC and section 51, Act 613. The former gives discretionary power to the Registrar to enter or not the Registrar's caveat. In comparison, the latter imposes a mandatory duty to endorse upon receiving the notice of seizure. Upon receiving the notice from the Public Prosecutor, the Registrar of Titles must act as soon as feasible to endorse the seizure notice that failure to do will result in a criminal penalty imposed on the Registrar. However, the language of section 51 of Act 613 does not 
explicitly mention that a Registrar is required to enter Registrar's Caveat. Accordingly, nowhere in the NLC imposes on the Registrar to endorse any other freezing order such as seizure notice and sale. Furthermore, the only stopping order under the NLC is the Registrar Caveat.

In New Zealand, besides the statute, the Land Information New Zealand (LINZ) is a public service department that plays a vital role in the maintenance and smooth operation of the regulatory framework and systems for lands transactions in New Zealand. Simultaneously, LINZ is responsible for managing property rights and land transactions. It also serves as the core administrator relating to land data, especially in keeping and monitoring the land data record for the benefit of the public. In dealing with caveats and other stops on registration, such as freezing orders, LINZ provides guidelines published on 14 November 2018, where there is a legal "stop" on registration, the Registrar-General of Land's role is to prevent or restrict transactions being entered (Guidelines LINZG20773, 2018). In 2018, the Office of the Registrar-General of Land under the Land Information of New Zealand (LINZ), the administrative body that governs the registration of land transactions, provides a clear guideline as to the duty of the Registrar. Besides a duty to enter a caveat, also a duty to honour freezing orders from other authorised legislation. LINZ stipulates two freezing orders, firstly the Freezing Order (formerly known as Mareva Injunction under Part 32 of the High Court Rules 2016 and the Asset Protection Order under Section 207 of the Insolvency Act 2006 (Guideline 2018, LINZ). This sub-paragraph incorporates the type of freezing order and also the Authorising Legislation. Ultimately, such inclusion in the Guidelines clarifies and enhances the statutory duties of the Registrar under the land statute.

\section{Conclusion}

The absence of guidelines or explicit provisions of the extent of the statutory duties imposed on the Registrar may become a grey area in defining the discretionary powers. As the custodian of Register Documents of Titles, the Registrar plays a vital role in ensuring and safeguarding property rights. The Registrar is responsible for carrying out the duties provided under the NLC. When another written statute imposes legal obligations in the form of freezing orders on the Registrar, it should be clarified in the NLC to safeguard the Registrar from any non-compliance. Adopting the New Zealand LINZ Guidelines is timely to diffuse conflicts between the officers of the Authorising Legislation and the Registrar.

The NLC is silent on the power of the Registrar relating to any freezing order application under another legislation on land. Hence, imposing a duty on the Registrar to honour the freezing order's application instead of his duty to facilitate land transactions could affect any interested parties in a land transaction. It is unfair to the parties in land transactions if the RDT is straightforward and does not indicate any freezing order or encumbrances to obtain an effective registration. The primary statutory duty of the Registrar is to determine the fitness of registration and enter a Registrar Caveat if any of the reasons specified under Section 320 of the NLC is proven and he has a discretionary power to withdraw the Registrar Caveat on his own motion. It is suggested that the freezing orders from other legislation are specified clearly under the NLC or Guidelines before the Registrar is imposed with a statutory duty to honour such application. In 2018, the Office of the Registrar-General of Land under the Land Information of New Zealand (LINZ), administrative body that governs the registration of land transactions, provides a clear guideline as to the duty of the Registrar. Besides a duty to enter caveat, also a duty to honour freezing orders from other authorised legislation. LINZ stipulates two freezing orders, firstly the Freezing Order (formerly known as Mareva Injunction under Part 32 of the High Court Rules 2016 and the Asset Protection Order under Section 207 of the 
Insolvency Act 2006 (Guideline 2018, LINZ).

The Registrar is imposed with the legal duty to act according to the NLC and any application made to the Registrar without any clear provisions under the NLC could create a gap where discretionary power should be used. (Vitanski, 2015) reviews that a discretionary power can be given to a certain government authority solely on legal grounds that precisely determines the framework of this authorization and to allow lawful, efficient and responsible operation of the administrative system. Such gap could create an uncertainty in the exercising of the discretionary power that may posed potential corruptive hotspots.

\section{References}

Applegate, A. G. (1982). "Prosecutorial Discretion and Discrimination in the Decision to Charge." Maurer Faculty. Paper 1018. http://www.repository.law.indiana.edu/facpub/1018.

Azad, H. (2020), Monitoring land governance: Understanding roots and shoots, Land Use Policy, Volume 94, May 2020, 104530; https://doi.org/10.1016/j.landusepol.2020.104530.

Cooper, S. (2018). Correction of the Register and Mistake by Omission. Conveyancer and Property Lawyer, 2018 (3).

Cooper, S. (2019). Registry Entry Pursuant to a Court Order Subsequently Set Aside. Conveyancer and Property Lawyer, 83 (1).

Das, S. K. (Ed.) (1963) The Torrens System in Malaya, (Malayan Law Journal Ltd.).

Deininger, K., Selod, H., Burns, T. (2011), The land governance assessment framework: identifying and monitoring good practice in the land sector World Bank, Washington.

Enemark, S., McLaren, R., Van Der Molen, P. (2010), "Land Governance in Support of the Millennium Development Goals: A New Agenda for Land Professionals", in XXIV FIG International congress 2010. Facing the challenges - building the capacitycharge16 April 2010, Sydney, Australia: technical programme and proceedings, Copenhagen, International Federation of Surveyors (FIG), 2010.

Gisselquist, R. M. (2012): Good governance as a concept, and why this matter for development policy, WIDER Working Paper, No. 2012/30, ISBN 978-92-9230-493-5, The United Nations University World Institute for Development Economics Research (UNU-WIDER), Helsinki.

Lavigne, D. P. (2007). Changes in'customary'Land Management Institutions: evidence from West Africa. In: Cotula, L. (Ed.), Changes in 'Customary' Land Tenure, Systems in Africa. IIED, London, pp. 35-50.

Abu Bakar, N. (2016), Security of Tenure in the Computerized Land Registration System: A Myth, The Social Science 11 (Special Issue 6): 7310-7313, 2016 ISSN 1818-5800.

Abu Bakar, N. (2019), "The Implication of Fraud on Security of Tenure under the Conveyancing Law and Practices in West Malaysia". PhD, Universiti Teknologi Mara, Malaysia.

Omar, H., Mansoor, M., Ramli, L., \& Salleh, M. H. F. (2020), Corruption and Accountability of Public Officials: Comparative analysis from Malaysia and Indonesia. vol. 5 No. 15, 269274 (2020) Dec. AIVCE-BS-2, 2020ShahAlam, 2nd Series, 02-03 Dec 2020, DOI: https://doi.org/10.21834/ebpj.v5i15.

Teo, K. S. (2012), Land Law in Malaysia: Cases and Commentary, Lexis Nexis, Malaysia, ISBN978-967-400-082-0(hc).

Wong, D. S. Y. (1972), Tenure and Land Dealings in the Malay States, Singapore University Press.

Vitanski, D. (2015), (JPMNT) Journal of Process Management - New Technologies, 
INTERNATIONAL JOURNAL OF ACADEMIC RESEARCH IN BUSINESS AND SOCIAL SCIENCES Vol. 11, No. 10, 2021, E-ISSN: 2222-6990 @ 2021 HRMARS

International Vol. 3, No.2 assessed at https://scindeks-clanci.ceon.rs/data/pdf/2334$735 X / 2015 / 2334-735 X 1502027$ V.pdf on 19/9/2021. 